DOI: $10.20961 /$ jpscr.v3i2.22162

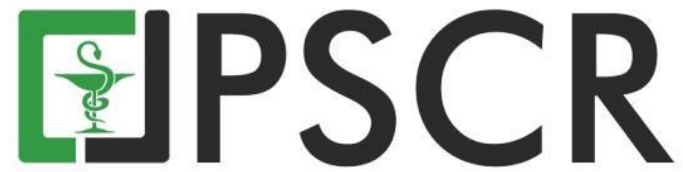

\title{
Analisis Kepuasan Pasien BPJS Rawat Jalan terhadap Pelayanan Instalasi Farmasi Rumah Sakit UNS
}

\author{
Niken Kusuma Astuti ${ }^{1}$ dan Wisnu Kundarto ${ }^{1 *}$ \\ ${ }^{1}$ Program Studi D3 Farmasi, Fakultas Matematika dan Ilmu Pengetahuan Alam, Universitas Sebelas Maret \\ *email korespondensi: wisnukundarto.apt@gmail.com
}

\begin{abstract}
Abstrak: Rumah sakit UNS merupakan rumah sakit pendidikan milik UNS yang juga memberikan pelayanan untuk pasien BPJS. Belum ada penelitian terkait kepuasan pasien BPJS rawat jalan terhadap pelayanan kefarmasian di rumah sakit tersebut. Tujuan penelitian ini yaitu mengetahui profil tingkat kepuasan dan prioritas perbaikan yang perlu dilakukan di instalasi farmasi rumah sakit UNS terhadap pelayanan kefarmasian pada pasien BPJS rawat jalan. Penelitian ini termasuk non-eksperimental bersifat deskriptif menggunakan kuesioner. Responden dipilih dengan teknik convenience sampling. Untuk mengetahui tingkat kepuasan pasien dan evaluasi pelayanan digunakan metode SERVQUAL. Sedangkan, untuk mengetahui prioritas perbaikan dilakukan analisis dengan Customer Window Quadrant. Hasil penelitian menunjukan tingkat kepuasan pada dimensi tangible, reliability, assurance, responsiveness, dan empati berturut-turut sebesar 94,24\%, 94,80\%, 91,11\%, 95,70\%, dan 93,96\%. Sedangkan, prioritas utama yang perlu dilakukan IFRS UNS yaitu kecepatan pelayanan kefarmasian, dan pemberian informasi mengenai obat secara lebih mendetail.
\end{abstract}

Kata kunci: SERVQUAL; Customer Window Quadrant; Tingkat Kepuasan; BPJS

\begin{abstract}
Satisfaction Analysis of Outpatient BPJS Patient on Pharmacy Service in UNS Hospital. UNS hospital is an educational hospital owned by UNS, which give the services to the patients, include for BPJS patients. There is no previous research which analyze BPJS outpatient's satisfaction for pharmacy service in UNS hospital. The aim of this research is to find out the profile of satisfaction level and the improvement priority which need to be done in Pharmacy Installation of UNS hospital for outpatient of BPJS. This research was descriptive non-experimental research. Data were taken by questionnaire. The respondents were chosen by convenience sampling technique. SERVQUAL methods was used to find out the satisfaction level of the patients and the service evaluation. While, to find out the improvement priority, the analysis with Customer Window Quadrant was conducted. The results of the research showed that the satisfaction level on tangible, reliability, assurance, responsiveness, and empathy was $94,24 \%, 94,80 \%, 91,11 \%, 95,70 \%$, and $93,96 \%$ respectively. While, the main priority that needs to be done by Pharmacy Installation of UNS Hospital are pharmaceutical service speed, and information provision about the drug in more detail.
\end{abstract}

Keywords: SERVQUAL; Customer Window Quadrant; Satisfaction Level; BPJS 


\section{Pendahuluan}

Data Kementerian Kesehatan RI tahun 2017, di Kabupaten Sukoharjo terdapat 10 rumah sakit dengan 5 diantaranya memiliki tipe rumah sakit C. Sebagai rumah sakit yang baru didirikan, rumah sakit UNS dituntut untuk memberikan pelayanan yang berkualitas guna dapat bersaing dengan rumah sakit lain di Kabupaten Sukoharjo. Upaya dalam meningkatkan dan menjaga mutu pelayanan merupakan prioritas utama dalam manajemen pelayanan kesehatan rumah sakit. Rumah sakit UNS dalam pelayanannya menerima pasien umum maupun pasien penerima jaminan kesehatan yang diselenggarakan oleh BPJS Kesehatan. Berdasarkan jumlah kunjungan pasien di RS UNS pada tahun 2017, mayoritas adalah pengguna BPJS sebesar 79\%. Oleh karena itu, pelayanan untuk pasien BPJS menjadi prioritas untuk dilakukan evaluasi.

Kualitas pelayanan kesehatan merupakan faktor yang harus diperhatikan oleh rumah sakit sebagai sarana pelayanan kesehatan, terutama setelah dilaksanakannya program jaminan kesehatan. Kualitas pelayanan dapat dinilai dari tingkat kepuasan pasien. Kepuasan pasien merupakan perasaan senang yang muncul di dalam diri seorang setelah mendapat pelayanan yang diterima atau dialami secara langsung (Mardiana,2016).

Salah satu pelayanan yang disediakan di rumah sakit UNS adalah pelayanan kefarmasian. Mutu pelayanan farmasi dapat dianalisa menggunakan metode Service Quality (SERVQUAL), yaitu metode yang mengukur kualitas jasa berdasarkan lima dimensi pokok yang meliputi sarana dan prasarana (tangible); kehandalan (reliability); kualitas pelayanan yang tanggap (responsiveness); memberikan rasa percaya serta keyakinan (assurance); serta pelayanan yang baik dan pemahaman kebutuhan pasien (empathy) dalam pelayanan di rumah sakit (Risha dan Umi, 2014). Untuk memberikan gambaran prioritas yang harus ditingkatkan pada pelayanan kefarmasian digunakan metode Customer Window Quadrant (CWQ). Customer Window Quadrant adalah suatu alat analisis kesenjangan untuk memahami kepuasan dan kepentingan relatif pelanggan terhadap jasa yang diperoleh (Handayani dan Gamayanto, 2015).

Penelitian ini bertujuan untuk mengetahui profil tingkat kepuasan pasien BPJS terhadap pelayanan kefarmasian di rumah sakit UNS serta evaluasi perbaikan pelayanan yang perlu dilakukan oleh Instalasi Farmasi Rumah Sakit UNS (IFRS UNS). Penelitian ini berfokus ke pelayanan IFRS UNS terhadap pasien BPJS rawat jalan.

\section{Metode Penelitian}

Penelitian ini merupakan penelitian non-eksperimental deskriptif dengan metode survey dan wawancara. Penelitian ini telah mendapat surat kelaikan etik dari Fakultas Kedokteran UNS dengan nomor 305/III/HREC/2018. Penelitian menggunakan alat ukur kuesioner mengacu pada 
kuesioner Maharani (2014) serta Handayani \& Yuniar (2016) dengan modifikasi yang dilakukan pada pilihan item jawaban. Sebelum dilakukan penelitian kuesioner terlebih dahulu dilakukan uji validitas dan uji reliabilitas. Skala yang digunakan pada penelitian ini yaitu skala likert karena skala likert memiliki reliabilitas yang relatif tinggi dan memberikan keterangan yang lebih nyata berdasarkan pendapat responden (Nasir,dkk., 2011).

\subsection{Teknik sampling}

Dalam penelitian ini, teknik pengambilan sampel yang digunakan adalah nonprobability sampling dengan teknik convenience sampling. Jumlah sampel minimal ditentukan dengan rumus populasi diketahui mengacu pada rumus Riyanto (2011). Sedangkan, subjek penelitian dipilih berdasarkan kriteria yaitu pasien pengguna fasilitas BPJS, telah merasakan pelayanan di IFRS UNS minimal 2 kali, berusia lebih dari 17 tahun, menguasai baca tulis, dapat berkomunikasi dengan baik, serta bersedia mengisi informed consent.

\subsection{Analisis data}

\subsubsection{Uji validitas dan uji reliabilitas}

Validitas adalah suatu indeks yang menunjukkan alat ukur itu benar- benar mengukur hal yang diukur. Kuesioner dikatakan valid apabila koefisien korelasi ( $\mathrm{r}$ hitung > r tabel) maka pernyataan tersebut valid dan jika sig (2- tailed) $<0,05$ berarti pernyataan tersebut valid (Ghozali, 2006). Reliabilitas adalah indeks yang dipakai untuk menunjukkan sejauh mana suatu alat pengukur dapat dipercaya atau dapat diandalkan. kuesioner dikatakan reliabel jika memberikan nilai cronbach alpha > 0,6 (Ghozali, 2006).

\subsubsection{Analisis SERVQUAL}

Metode SERVQUAL terdiri dari tangible, reliability, responsiveness, assurance, dan empathy. Data diolah menggunakan untuk mendapatkan rerata pada setiap butir pertanyaan yang sudah diskoring di setiap dimensi mutu pelayanan. Setiap jawaban responden didalam kuesioner akan diberikan skor yang disusun berdasarkan skala likert setiap jawaban pada tiap dimensi mutu. Pengukuran tingkat kepuasan dilakukan dengan membandingkan antara skor kinerja yang diperoleh pasien dengan skor harapan pada pelayanan dari masing-masing dimensi mutu pelayanan yaitu tangible, reliability, assurance, responsiveness, empathy. Menurut Supranto (2001), rumus yang dipakai untuk mengukur tingkat kepuasan konsumen sebagai berikut:

$$
T K=\frac{\text { Kinerja }}{\text { Harapan }} \times 100 \%
$$


Keterangan:

TK : Tingkat Kepuasan

$\mathrm{K}:$ Kenyataan Kinerja

$\mathrm{H}$ : Harapan Pasien

2.3.3. Customer Window Quadrant (CWQ)

Untuk melihat kepentingan relatif pelanggan dapat dilihat pada kuadran jendela pelanggan atau Customer Window Quadrant (CWQ). Kuadran jendela pelanggan adalah suatu alat analisis kesenjangan untuk memahami kepuasan dan kepentingan relatif pelanggan terhadap jasa yang diperoleh. CWQ membagi karakteristik produk ke dalam empat kuadran. Kuadran A menggambarkan kondisi harapan tinggi sedangkan kinerja rendah atau belum maksimal. Kuadran B mengambarkan item yang memiliki harapan tinggi dengan kinerja tinggi. Kuadran C menggambarkan kondisi harapan rendah tetapi kinerja tinggi. Serta, kuadran D menggambarkan kondisi harapan rendah dan kinerja rendah (Handayani dan Gamayanto, 2015).

\section{Hasil dan Pembahasan}

Penelitian dilaksanakan di Instalasi Farmasi rawat Jalan Rumah Sakit UNS pada bulan Maret 2018. Berdasarkan jumlah populasi pasien pada bulan Januari 2018 sebesar 3241, maka dapat ditetapkan jumlah sampel minimal sebesar 93 responden. Perhitungan sampel minimal mengacu Riyanto (2011) dengan menggunakan nilai tingkat kepercayaan 95\%, dan nilai penyimpangan 0,1. Jumlah responden pada penelitian ini sebesar 173 pasien (tidak termasuk responden uji validitas dan reliabilitas kuesioner) dan diambil di bulan Maret 2018.

\subsection{Uji validitas dan uji reliabilitas}

Uji validitas dan reliabilitas dilakukan kepada 30 responden sesuai kriteria. Berdasarkan uji statistik yang dilakukan pada 5 dimensi mutu pelayanan nilai r pada tiap dimensi mutu sudah menunjukkan angka lebih dari 0,361. Oleh karena itu, pertanyaan dalam kuesioner dapat dikatakan valid. Hasil uji reliabilitas pada tingkat kinerja dan harapan, nilai cronbach alpha untuk tingkat harapan yaitu sebesar 0,737 dan nilai cronbach alpha untuk tingkat kinerja sebesar 0,884 . Hasil tersebut menunjukkan bahwa nilai cronbach alpha untuk kedua tingkat sudah lebih dari 0,6. Oleh karena itu, kuesioner dapat dikatakan reliabel sehingga mampu memberikan hasil pengukuran yang konsisten dari waktu ke waktu.

\subsection{Profil dan evaluasi tingkat kepuasan pasien BPJS di Instalasi Farmasi Rawat Jalan Rumah Sakit UNS}

Berdasarkan pengolahan data dengan menggunakan perbandingan skor rata-rata pada tingkat kinerja dan harapan, maka hasil tingkat kepuasan pasien dapat dilihat pada tabel 1. Hasil 
menunjukan bahwa tingkat kepuasan pasien pada kelima dimensi mutu pelayanan termasuk dalam kategori sangat puas menurut Ihsani (2005). Hal ini diperkuat dengan hasil pada tiap dimensi mutu pelayanan sudah menunjukan angka lebih dari 90\%. Namun apabila dilihat pada tiap item penilaian, terdapat 3 item yang masuk dalam kategori puas dikarenakan tingkat kepuasan berada pada rentang $66 \%$ - 80,99\%. Item penilaian tersebut yaitu pada dimensi Assurance item 13 yaitu "pemberian informasi efek samping obat" berdasarkan wawancara dengan responden petugas jarang memperhatikan informasi tentang efek samping obat tetapi ada beberapa pasien yang mengalami gejala efek samping sederhana seperti mual, mengantuk. Selain itu, informasi efek samping obat diperlukan agar pasien atau responden lebih waspada terhadap kondisi pasien setelah minum obat dan item 14 yaitu "pemberian informasi tentang makanan dan minuman yang perlu dihindari selama pengobatan" berdasarkan wawancara dengan responden petugas tidak memberikan tentang hal - hal yang harus dihindari ketika pengobatan sebagian pasien mengatakan bahwa petugas kurang menginformasikan hal tersebut seperti makanan atau minuman yang harus dihindari ataupun pantangan yang harus dihindari ketika pengobatan seperti obat tertentu yang tidak bisa dikonsumsi secara bersamaan ketika pengobatan. serta pada dimensi empathy pada item 19 yaitu "pemantauan penggunaan obat sebelumnya" menurut hasil wawancara dengan responden, petugas apotek hanya sesekali menanyakan atau melakukan pemantauan penggunaan obat.

Tingkat kepuasan tertinggi yaitu pada dimensi reliability item 7 "Ketika pasien bertanya petugas dapat menjawab dengan jelas" dengan nilai sebesar 107,43\%. Tingkat kepuasan yang melebihi $100 \%$ menyatakan bahwa pelayanan petugas mengenai item ini sudah melebihi harapan pasien, sehingga dapat dikatakan bahwa petugas mampu memberikan respon yang baik ketika pasien menanyakan sesuatu hal. Sedangkan, tingkat kepuasan paling rendah yaitu pada dimensi assurance pada item 14.

\subsection{Prioritas Perbaikan dengan Metode Customer Window Quadrant (CWQ)}

Kuadran pada metode CWQ dibagi menjadi 4 kuadran, tiap kuadran memberikan gambaran prioritas perbaikan yang perlu dilakukan Instalasi Farmasi Rumah Sakit UNS. Gambar 1 merupakan hasil analisis Customer Window Quadrant. Berdasarkan hasil analisis CWQ pada gambar 1 maka terdapat 3 item yang menjadi prioritas perbaikan yang harus dilakukan Instalasi Farmasi Rawat Jalan Rumah Sakit UNS yaitu pada kuadran A. Prioritas perbaikan yang pertama yaitu pada item 4 "Petugas apotek melakukan pelayanan resep dengan cepat dan tepat". Berdasarkan hasil wawancara dan observasi, responden mengeluhkan waktu tunggu di apotek lama. Berdasarkan SOP pelayanan petugas perlu menginformasikan waktu tunggu obat kepada 
pasien dan menyerahkan nomor antrian sesuai jenis obat yaitu racikan atau bukan racikan. Tetapi berdasarkan observasi petugas tidak menyampaikan waktu tunggu kepada pasien dan tidak memberikan nomor antrian kepada pasien. Waktu tunggu yang lama menyebabkan penumpukan pasien di ruang tunggu apotek terutama pada jam - jam tertentu.

Tabel 1. Data Kepuasan Pasien pada Masing - Masing Dimensi Mutu

\begin{tabular}{|c|c|c|c|c|c|c|}
\hline Item No & Pernyataan & $\begin{array}{c}\text { Skor } \\
\text { Kinerja }\end{array}$ & $\begin{array}{c}\text { Nilai } \\
\text { SD }\end{array}$ & $\begin{array}{c}\text { Skor } \\
\text { Harapan }\end{array}$ & $\begin{array}{c}\text { Nilai } \\
\text { SD }\end{array}$ & $\begin{array}{l}\text { Tingkat } \\
\text { Kepuasan } \\
(\%)\end{array}$ \\
\hline \multicolumn{7}{|c|}{ Tangibel (Bukti nyata) } \\
\hline 1 & $\begin{array}{l}\text { Obat yang tersedia di apotek } \\
\text { lengkap }\end{array}$ & 2,71 & 0,48 & 2,84 & 0,36 & $95.42 \%$ \\
\hline 2 & $\begin{array}{l}\text { Ruang tunggu apotek } \\
\text { nyaman, bersih dan tertata } \\
\text { rapi }\end{array}$ & 2,55 & 0,64 & 2,78 & 0,42 & $91,73 \%$ \\
\hline 3 & $\begin{array}{l}\text { Kondisi loket penyerahan } \\
\text { obat memadai }\end{array}$ & 2,61 & 0,56 & 2,72 & 0,46 & $95,96 \%$ \\
\hline & Rata - Rata & 2,62 & & 2,78 & & $94,24 \%$ \\
\hline \multicolumn{7}{|c|}{ Reliability (Kehandalan) } \\
\hline 4 & $\begin{array}{l}\text { Resep dilayanai dengan } \\
\text { cepat \& tepat }\end{array}$ & 2,44 & 0,55 & 2,72 & 0,46 & $89,70 \%$ \\
\hline 5 & $\begin{array}{l}\text { Pemberian informasi } \\
\text { tentang cara penyimpanan } \\
\text { obat }\end{array}$ & 2,27 & 0,68 & 2,61 & 0,5 & 86,97 \\
\hline 6 & $\begin{array}{l}\text { Pemberian informasi } \\
\text { tentang cara penggunaan } \\
\text { obat }\end{array}$ & 2,62 & 0,57 & 2,73 & 0,44 & $95,97 \%$ \\
\hline \multirow[t]{3}{*}{7} & $\begin{array}{l}\text { petugas dapat menjawab } \\
\text { pasien dengan jelas }\end{array}$ & 2,89 & 0,31 & 2,69 & 0,48 & $107,43 \%$ \\
\hline & Rata - Rata & 2,55 & & 2,69 & & $94,80 \%$ \\
\hline & \multicolumn{6}{|l|}{ Assurance (Jaminan) } \\
\hline 8 & $\begin{array}{l}\text { Petugas memastikan } \\
\text { kebenaran penerima obat }\end{array}$ & 3 & 0 & 2,86 & 0,35 & $104,90 \%$ \\
\hline 9 & $\begin{array}{l}\text { Petugas apotek } \\
\text { memberikan informasi } \\
\text { dengan bahasa yang } \\
\text { mudah dimengerti }\end{array}$ & 2,90 & 0,31 & 2,77 & 0,42 & $104,69 \%$ \\
\hline 10 & $\begin{array}{l}\text { Petugas apotek } \\
\text { mengkonfirmasi kejelasan } \\
\text { informasi yang diberikan }\end{array}$ & 2,51 & 0,63 & 2,64 & 0,51 & $95,08 \%$ \\
\hline 11 & $\begin{array}{l}\text { pemberikan informasi } \\
\text { tentang nama obat dan } \\
\text { khasiat obat }\end{array}$ & 2,31 & 0,6 & 2,74 & 0,47 & $84,31 \%$ \\
\hline 12 & $\begin{array}{l}\text { Pemberikan informasi } \\
\text { tentang aturan pemakaian } \\
\text { obat dan lamanya } \\
\text { penggunaan obat }\end{array}$ & 2,58 & 0,53 & 2,76 & 0,43 & $93,44 \%$ \\
\hline 13 & $\begin{array}{l}\text { Pemberikaninformasi } \\
\text { tentang efek samping obat }\end{array}$ & 2,13 & 0,72 & 2,69 & 0,48 & $79,18 \%$ \\
\hline
\end{tabular}


Lanjutan Tabel 1. Data Kepuasan Pasien pada Masing - Masing Dimensi Mutu

\begin{tabular}{|c|c|c|c|c|c|c|}
\hline Item No & Pernyataan & $\begin{array}{c}\text { Skor } \\
\text { Kinerja }\end{array}$ & $\begin{array}{c}\text { Nilai } \\
\text { SD }\end{array}$ & $\begin{array}{c}\text { Skor } \\
\text { Harapan }\end{array}$ & $\begin{array}{c}\text { Nilai } \\
\text { SD }\end{array}$ & $\begin{array}{c}\text { Tingkat } \\
\text { Kepuasan } \\
(\%)\end{array}$ \\
\hline \multirow[t]{2}{*}{14} & $\begin{array}{l}\text { Pemberikan informasi } \\
\text { tentang yang harus } \\
\text { dihindari selama } \\
\text { pengobatan }\end{array}$ & 1,80 & 0,76 & 2,47 & 0,66 & $72,87 \%$ \\
\hline & Rata - Rata & 2,46 & & 2,70 & & $91,11 \%$ \\
\hline \multicolumn{7}{|c|}{ Responsiveness (Ketanggapan) } \\
\hline 15 & $\begin{array}{l}\text { Kecepatan Petugas } \\
\text { loket melayani pasien }\end{array}$ & 2,57 & 0,56 & 2,72 & 0,45 & $94,48 \%$ \\
\hline 16 & $\begin{array}{l}\text { Petugas apotek } \\
\text { memberikan informasi } \\
\text { sebelum pasie bertanya }\end{array}$ & 2,53 & 0,60 & 2,61 & 0,55 & $96,93 \%$ \\
\hline Rata - Rata & & 2,55 & & 2,67 & & $95,70 \%$ \\
\hline \multicolumn{7}{|c|}{ Empathy (empati) } \\
\hline 17 & \begin{tabular}{lr}
\multicolumn{2}{l}{ Petugas memberikan } \\
pelayanan & dengan \\
baik & tanpa \\
memandang & status \\
sosial &
\end{tabular} & 2,94 & 0,24 & 2,80 & 0,43 & $105 \%$ \\
\hline 18 & $\begin{array}{l}\text { Petugas apotek } \\
\text { melayani dengan ramah } \\
\text { dan tersenyum }\end{array}$ & 2,64 & 0,48 & 2,76 & 0,43 & $95,65 \%$ \\
\hline 19 & $\begin{array}{l}\text { Pemantauan } \\
\text { penggunaan obat } \\
\text { sebelumnya }\end{array}$ & 2,07 & 0,72 & 2,58 & 0,57 & $80,23 \%$ \\
\hline Rata - Rata & & 2,55 & & 2,71 & & $93,96 \%$ \\
\hline
\end{tabular}

Prioritas perbaikan kedua yaitu pada item 11 "Petugas apotek memberikan informasi tentang nama obat dan khasiat obat" berdasarkan wawancara dengan pasien petugas hanya menyampaikan khasiat atau kegunaan nama obat saja tanpa menyebutkan nama obat itu sendiri. Sehingga pasien akan selalu menghafal bentuk atau warna kemasan tanpa mengetahui nama obat yang digunakan dan ketika pasien mendapat obat dengan bentuk atau kemasan baru akan menimbulkan keluhan.

Prioritas perbaikan ketiga yaitu item 13 "Petugas memberikan informasi tentang efek samping obat "Berdasarkan wawancara dengan responden petugas jarang memperhatikan informasi tentang efek samping obat tetapi ada beberapa pasien yang mengalami gejala efek samping sederhana seperti mual, mengantuk. Selain itu, informasi efek samping obat diperlukan agar pasien atau responden lebih waspada terhadap kondisi pasien setelah minum obat. 
Keterbatasan pada penelitian ini yaitu tidak dilakukan penelitian mengenai hubungan karakteristik responden dengan tingkat kepuasan pasien dan tidak dilakukan pengujian ada tidaknya perbedaan yang signifikan antara nilai kinerja dan harapan.

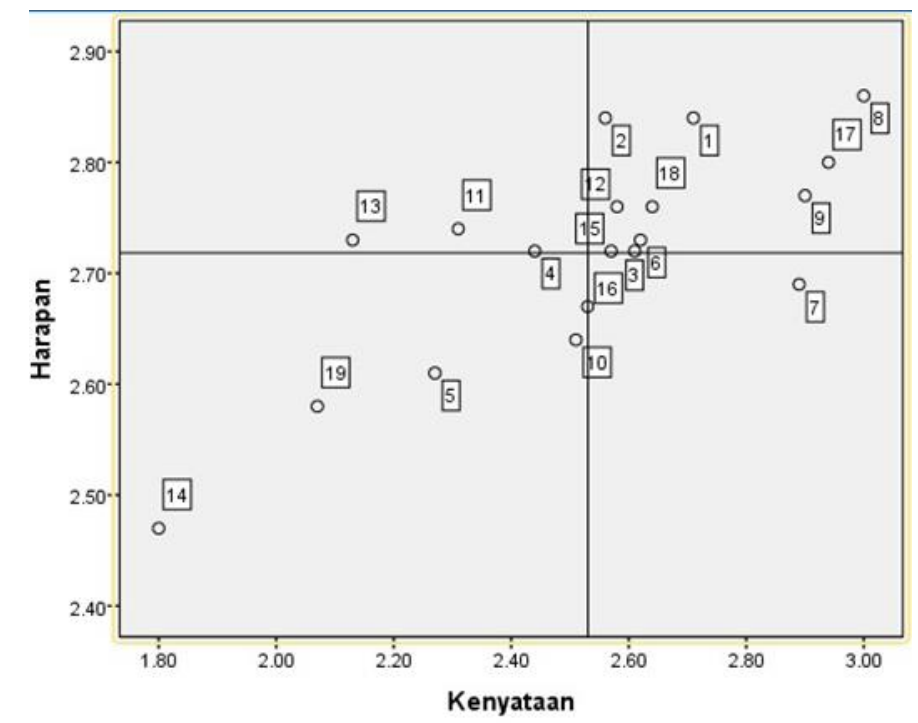

Gambar 1. Hasil analisis kuadran jendela pelanggan (customer window quadrant)

\section{Kesimpulan}

Hasil penelitian menunjukkan tingkat kepuasan pasien BPJS rawat jalan pada tiap dimensi mutu sudah masuk dalam kategori sangat puas (>90\%). Hasil analisis Customer Window Quadrant menunjukkan petugas IFRS UNS sebaiknya memperbaiki kecepatan dan ketepatan pelayanan resep, menyampaikan waktu tunggu, memberikan nomor antrian, memberikan informasi tentang nama dan khasiat obat, serta memberikan informasi efek samping obat kepada pasien.

\section{Ucapan Terimakasih}

Penulis mengucapkan terimakasih kepada pihak rumah sakit UNS yang telah memberikan izin untuk melakukan penelitian ini. Serta kepada semua pihak yang membantu selama proses penelitian.

\section{Daftar Pustaka}

Ghozali, I., 2006, Analisis Multivariate dengan Program SPSS (Edisi ke 5), Badan Penerbit Universitas Diponegoro, Semarang.

Handayani, W., dan Gamayanto, I., 2015, Perancangan Business Online Heynis Hijab Untuk Meningkatkan Penjualan Dengan Menggunakan Metode Jendela Pelanggan (Customer Window), Skripsi, Fakultas Ilmu Komputer, Universitas Dian Nuswantoro

Handayani, R.S., dan Yuniar, Y., 2016, Kepuasan Pasien Peserta Program Jaminan Kesehatan Nasional terhadap Pelayanan Kefarmasian di Apotek, Jurnal Kefarmasian Indonesia,Vol6(1) 39-48. 
Maharani, E., 2014, Analisis Kepuasan Pasien BPJS Terhadap Pelayanan Farmasi di Apotek Rawat Jalan RSO Prof. Dr. R. Soeharso Surakarta, Tugas Akhir, FMIPA, Universitas Sebelas Maret, Surakarta.

Mardiana.D, 2016, Tinjauan Kepuasan Pasien BPJS Terhadap Pelayanan Petugas Tempat Pendaftaran Rawat Jalan di RSU Imelda Pekerja Indonesia Medan Tahun 2016.

Nasir, Muhith, dan Ideputri, 2011, Buku Ajar : Metode Penelitian Kesehatan kesehatan, Nuha Medika, Yogyakarta.

Risha, F.F., dan Umi, S., 2014, Perbandingan Kualitas Pelayanan Instalasi Farmasi Pasien BPJS Rawat Jalan Rumah Sakit Pemerintah dan Swasta Kota Semarang.

Riyanto, A., 2011, Aplikasi Metodologi Penelitian Kesehatan, Muha Medika, Yogyakarta.

Supranto, 2001, Pengukuran Tingkat Kepuasan Pelanggan, Rineka Cipta, Jakarta. 